\title{
Intraocular rituximab
}

\section{Eye (2007) 21, 1453-1454; doi:10.1038/sj.eye.6702976}

Primary central nervous system lymphoma (PCNSL) is a variant of extra-nodal nonHodgkin's lymphoma (NHL) that arises from specific sites including the brain, spinal cord, meninges, or eyes. ${ }^{1}$ The most common ophthalmologic manifestations are vitritis and subretinal pigment epithelial infiltrates. ${ }^{2-4}$ Intraocular involvement may be a presenting feature with subsequent central nervous system (CNS) involvement in $56-85 \%$ of patients over a period of many months to several years. ${ }^{2,5,6}$ Conversely, about $20 \%$ of patients with PCNSL have concurrent intraocular involvement. ${ }^{3,4}$

Management of PCNSL is still evolving and any treatment for ocular involvement should be undertaken in conjunction with an oncologist. ${ }^{4}$ The aim of treatment is to eradicate the ocular disease and to prevent subsequent CNS involvement. The traditional therapy with ocular radiation (40 Gy in divided doses) is ineffective in controlling the CNS disease. As the blood-brain barrier and blood-retina barrier are limiting factors that restrict drug entry into the CNS and eyes respectively, various strategies to circumvent these barriers have been developed. These include the use of highdose systemic chemotherapy, intrathecal drug delivery, intraventricular drug delivery by a reservoir, intravitreal injections, and temporary osmotic disruption of the blood-brain barrier with intra-arterial chemotherapy infusion. ${ }^{7}$ High-dose methotrexate $\left(8 \mathrm{~g} / \mathrm{m}^{2}\right)$ in combination with intrathecal methotrexate may not be sufficient for the treatment of ocular involvement even though therapeutic drug concentrations in the aqueous and vitreous may be achieved. ${ }^{8}$ Intravitreal methotrexate $(400 \mathrm{mg} / 0.1 \mathrm{ml})$ injected according to a standard induction-consolidation-maintenance regimen over a period of one year is effective in large proportion of cases. ${ }^{9}$ However, complications such as cataract and vitreous haemorrhage tend to be frequent and sight threatening., ${ }^{4,9}$

To avoid ocular complications of methotrexate, Kitzmann, et al ${ }^{10}$ have

AD Singh ${ }^{1}$ and DM Peereboom ${ }^{2}$

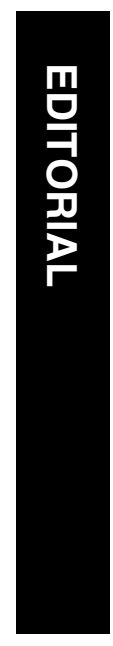

investigated the use of intravitreal rituximab and they report their initial observations in this issue of the journal. ${ }^{10}$ The choice of drug seems to be ideal. Rituximab is a humanized monoclonal mouse antibody that targets CD20positive $B$ cells and the vast majority of PCNL are composed of CD20-positive B cells. ${ }^{11,12}$ Human stem cells, progenitor cells, normal plasma cells, neurons, and glial cells in the brain do not express CD20 and therefore, are spared the effects of rituximab. ${ }^{13}$ Rituximab is effective and is approved for the treatment of previously untreated, relapsed or refractory, low-grade or follicular lymphoma, and diffuse large B-cell non-Hodgkin's lymphoma when given systemically. ${ }^{14}$ It has also been administered systemically as salvage therapy by itself or in combination with temozolomide as well as intrathecally for PCNSL with low neurotoxicity. ${ }^{15,16}$ Animal studies have also indicated the absence of retinal toxicity following a single injection of rituximab. ${ }^{17}$

However, several issues such as dose, frequency, duration, and delivery remain to be investigated further. The dose of $1 \mathrm{mg} / 0.1 \mathrm{ml}$ does provide intravitreal concentration in animal studies of more than $100 \mu \mathrm{g} / \mathrm{ml}$, a level that is effective in serum and cerebrospinal fluid. ${ }^{17}$ The half-life of 4.7 days implies that the injection should be repeated every 2 weeks rather than every 4 weeks to maintain therapeutic intravitreous levels. ${ }^{17}$ Intraocular injection with the associated risk of potentially serious side effects (endophthalmitis, vitreous haemorrhage, retinal detachment) every 2 weeks may not be accepted by patients (especially, patients with bilateral disease) for extended periods of time. The duration of treatment, clinically identifiable end point and therefore, the total number of injections to be prescribed remain to be established. Another issue with intraocular injection is the fact that more than $40 \%$ of the injected drug is lost in the first $48 \mathrm{~h}$, perhaps due to the efflux from the injection site, making this route of delivery very inefficient. ${ }^{17}$ The use of ocular drug delivery implants or delivery pumps may overcome
${ }^{1}$ Department of Ophthalmic Oncology, Cole Eye Institute, Taussig Cancer Center, Cleveland Clinic Foundation, Cleveland, $\mathrm{OH}$ USA

${ }^{2}$ Brain Tumor Institute, Taussig Cancer Center, Cleveland Clinic Foundation, Cleveland, $\mathrm{OH}$, USA

E-mail: singha@ccf.org

Correspondence: AD Singh, Department of Ophthalmic Oncology (i3-129),

Cole Eye Institute,

Cleveland Clinic

Foundation,

9500 Euclid Avenue,

Cleveland

Ohio 44195, USA

Tel: + 216445 9479;

Fax: + 2164452226

E-mail: singha@

ccf.org 
some of the issues. ${ }^{18,19}$ Although there is some evidence to suggest that rituximab can penetrate the retina and reach the subretinal layers, its effects on lymphomatous involvement in the subretinal pigment epithelial space is not known. ${ }^{17,20}$ Alternative routes of delivery include trans-scleral approach by subconjunctival injections. ${ }^{21}$

In summary, the use of intravitreous rituximab is a promising alternative to intravitreal methotrexate, but such treatment should be considered experimental at present and patients should be offered this treatment only within a framework of an investigational study.

\section{References}

1 Hochberg FH, Miller DC. Primary central nervous system lymphoma. J Neurosurg 1988; 68: 835-853.

2 Freeman LN, Schachat AP, Knox DL, Michels RG, Green WR. Clinical features, laboratory investigations, and survival in ocular reticulum cell sarcoma. Ophthalmology 1987; 94: 1631-1639.

3 Singh AD, Lewis H, Schachat AP. Primary lymphoma of the central nervous system. Ophthalmol Clin North Am 2005; 18: 199-207.

4 Singh AD, Lewis H, Schachat AP, Peereboom D. Lymphoma of the retina and CNS. In: Singh AD, Damato BE, Pe'er J (eds). Clinical Ophthalmic Oncology. Saunders-Elsevier: Philadelphia, 2007 pp 372-377.

5 Char DH, Ljung BM, Miller T, Phillips T. Primary intraocular lymphoma (ocular reticulum cell sarcoma) diagnosis and management. Ophthalmology 1988; 95: 625-630.

6 Peterson K, Gordon KB, Heinemann MH, DeAngelis LM. The clinical spectrum of ocular lymphoma. Cancer 1993; 72: 843-849.

7 Deangelis LM, Hormigo A. Treatment of primary central nervous system lymphoma. Semin Oncol 2004; 31: 684-692.

8 Batchelor TT, Kolak G, Ciordia R, Foster CS, Henson JW. High-dose methotrexate for intraocular lymphoma. Clin Cancer Res 2003; 9: 711-715.

9 Fishburne BC, Wilson DJ, Rosenbaum JT, Neuwelt EA. Intravitreal methotrexate as an adjunctive treatment of intraocular lymphoma. Arch Ophthalmol 1997; 115: 1152-1156.

10 Kitzmann AS, Pulido JS, Mohney BG, Baratz KH, Grube T, Marler RJ et al. Intraocular use of rituximab. Eye 2007; e-pub ahead of print.

11 Reff ME, Carner K, Chambers KS, Chinn PC, Leonard JE, Raab R et al. Depletion of B-cells in vivo by a chimeric mouse human monoclonal antibody to CD20. Blood 1994; 83: $435-445$.

12 Fine HA, Mayer RJ. Primary central nervous system lymphoma. Ann Intern Med 1993; 119: 1093-1104.

13 Maloney DG, Smith B, Rose A. Rituximab: mechanism of action and resistance. Semin Oncol 2002; 29: 2-9.

14 McLaughlin P, Grillo-Lopez AJ, Link BK, Levy R, Czuczrman MS, Williams ME et al. Rituximab chimeric anti-CD20 monoclonal antibody therapy for relapsed indolent lymphoma: half of patients respond to a four-dose treatment program. J Clin Oncol 1998; 16: 2825-2833.

15 Pels H, Schulz H, Schlegel U, Engert A. Treatment of CNS lymphoma with the anti-CD20 antibody rituximab: experience with two cases and review of the literature. Onkologie 2003; 26: 351-354.

16 Enting RH, Demopoulos A, DeAngelis LM, Abrey LE. Salvage therapy for primary CNS lymphoma with a combination of rituximab and temozolomide. Neurology 2004; 63: 901-903.

17 Kim H, Csaky KG, Chan CC, Bungay PM, Lutz RJ, Dedriok RL et al. The pharmacokinetics of rituximab following an intravitreal injection. Exp Eye Res 2006; 82: 760-766

18 Ghate D, Edelhauser HF. Ocular drug delivery. Expert Opin Drug Deliv 2006; 3: 275-287.

19 Saati S, Lo R, Li PY et al. Surgical methods to place a novel refillable ocular microelectromechanical system (MEMS) drug delivery device. Invest Ophthalmol Vis Sci 2007; 48: ARVO E-Abstract 5791.

20 Pulido JS, Bakri SJ, Valyi-Nagy T, Shukla D. Rituximab penetrates full thickness retina in contrast to tissue plasminogen activator. Retina 2007 (in press).

21 Ambati J, Gragoudas ES, Miller JW, You TT, Miyamoto K, Delori FC et al. Transscleral delivery of bioactive protein to the choroid and retina. Invest Ophthalmol Vis Sci 2000; 41: 1186-1191. 